Proc. Estonian Acad. Sci. Geol., 2006, 55, 1, 24-42

\title{
Intraspecific variation in Wenlock tabulate corals from Saaremaa (Estonia) and its taxonomic implications
}

\author{
Mari-Ann Mõtus \\ Institute of Geology at Tallinn University of Technology, Estonia pst. 7, 10143 Tallinn, Estonia; \\ motus@gi.ee \\ Received 5 October 2005, in revised form 28 November 2005

\begin{abstract}
Different aspects of intraspecific variation in Wenlock tabulate corals are discussed. Intracorallum and intraspecific variation is demonstrated in specimens within the collection from one locality. The diagnostic characters of Halysites senior Klaamann and Catenipora oriens Klaamann and those of Paleofavosites secundus (Klaamann) and Favosites jaaniensis Sokolov overlap and therefore these species are regarded as synonyms. Propora raricellata Sokolov is a possible synonym of $P$. tubulata (Lonsdale), because the character differentiating these species is variable.
\end{abstract}

Key words: Wenlock, Baltoscandia, tabulates, intraspecific variation.

\section{INTRODUCTION}

The taxonomy of tabulate corals in Baltoscandia was long based on the typological approach. Many species were erected where the intraspecific variation was not taken into account (Sokolov 1951a,b, 1952, 1955; Klaamann 1959, 1961, 1962a,b; Stasinska 1967). Later, Klaamann $(1964,1966,1970,1983)$ revised several species considering the intraspecific variability. It has been understood by now that the morphological variation in tabulate corals is very complex, having different aspects, and includes intraspecific and intracolonial components (Young \& Elias 1997). The aspects of morphological variation in Gotland tabulate corals are thoroughly studied by Stel (1978) and Young \& Scrutton (1991). It is also known that good taxonomical studies of tabulate corals with considering the intraspecific variation are based on complete collections of an adequate number of specimens representing different localities (Young \& Elias 1995; Dixon 1989, 1999).

The present research is based on material from one locality. The locality of Liiva on the northern coast of Saaremaa Island (Fig. 1) was selected for the study because tabulate corals are much more abundant there than in other Wenlock sites of Estonia. 


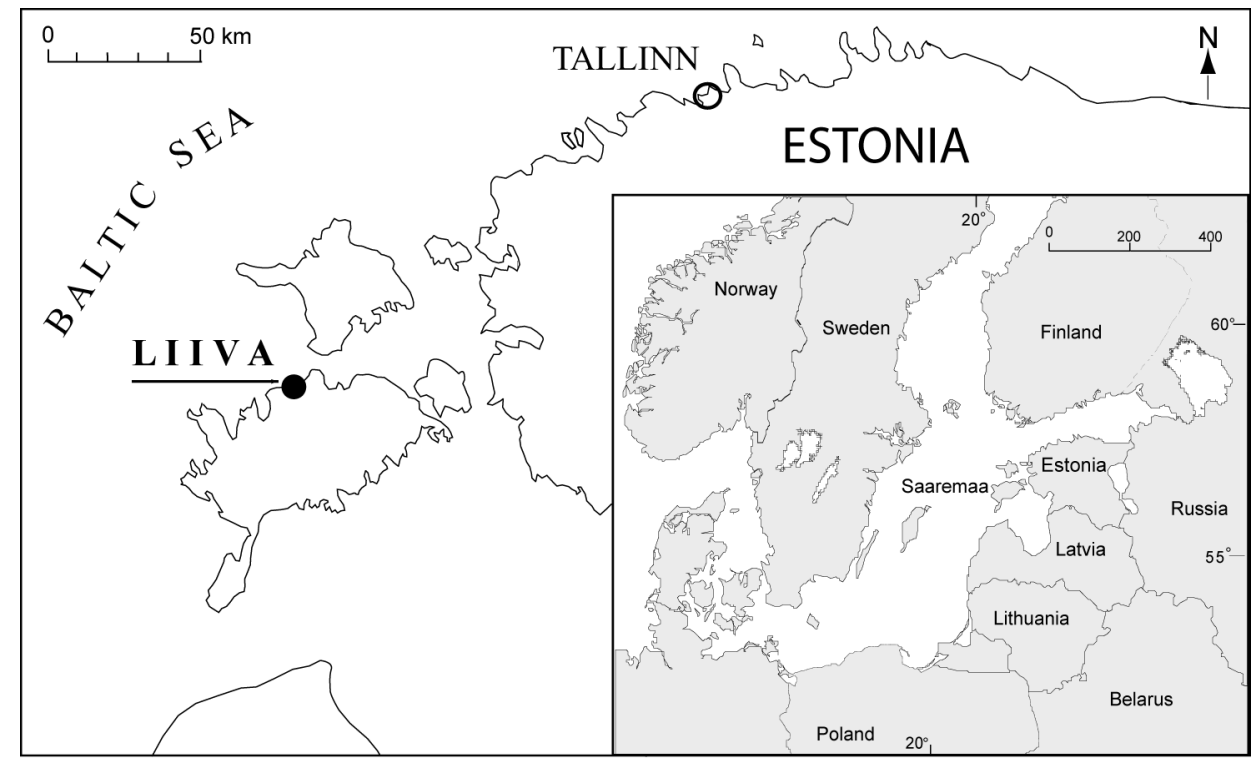

Fig. 1. Location map of the study site (Liiva locality).

The aspects of variation in Heliolites spongodes? Lindström, Heliolites interstinctus (Linnaeus), Heliolites sp. A, Propora tubulata (Lonsdale), Halysites senior Klaamann, and Paleofavosites secundus? (Klaamann) are analysed and the taxonomical problems of Wenlock tabulate corals in Baltoscandia are discussed. The main task is to characterize these species and show their intraspecific variability. One species is considered under open nomenclature and two species are tentative because more material is necessary for their precise identification.

\section{MATERIAL AND METHODS}

Populations are assumed to be stratigraphically and geographically limited collections of individuals, and the study of intraspecific variation requires that the examined collections be close to populations (Webb 1996; Dixon 1999). The morphological variation in tabulate corals occurs at different levels: within the corallum, within the population, and between populations (Dixon 1989; Webb 1996). Scrutton (1989) distinguished ontogenetic (visible development of the corallite), astogenetic (apparent development of the corallum), cyclomorphic (cycling of growth bands), and topomorphic (caused by environmental impacts) variation, expressed at the corallum level.

The present study deals with morphological variation at the corallum and intraspecific level, leaving aside details of ontogenetic variation. The collection analysed consists of 64 specimens from the Mustjala and Ninase members of the Jaani Formation from Liiva locality. 
The quantitative and non-quantitative data on intraspecific variation were received from thin sections by using the biometry and data on intracorallum variation were obtained from peels. Peels were made from selected coralla at $1 \mathrm{~cm}$ intervals.

The terminology and parameters of the corallum shape and size follow those of Young \& Scrutton (1991) and Young \& Elias (1995), and the measurement methods are largely based on the technique applied by Young \& Elias (1995). The coefficient of variation of mean parameters shows the variation between different heliolitid coralla in the current study. The coefficient of variation was calculated by the following formula: standard deviation/mean*100 (Simpson et al. 1960; Young \& Elias 1995).

The material is housed at the Museum of Geology, University of Tartu (TUG) and at the Institute of Geology at Tallinn University of Technology (GIT).

\section{GENERAL CHARACTERISTICS OF THE COLLECTION AND SURROUNDING FACIES}

The locality is only a few hundred metres long and about $2 \mathrm{~m}$ high. It comprises two different types of facies of the Jaani Stage (Klaamann 1986) - open shelf facies (Mustjala Member) and shoal facies (Ninase Member). The thickness of the upper part of the Mustjala Member above sea level is approximately $50 \mathrm{~cm}$. The overlying Ninase Member is about $1 \mathrm{~m}$ thick. The former consists of marlstone with interlayers and nodules of biomicritic limestone, the latter of grainstone (Fig. 2). The Mustjala Member contains tabulate corals, stromatoporoids, rugose corals, brachiopods, and crinoidal debris. The tabulate collection of the member is rich in heliolitids and halysitids, but poor in favositids, theciids, and syringolitids. Heliolitids and halysitids are common in the mudstone facies (Stel 1978; Scrutton 1998). Klaamann (1986) noted that species of the Mustjala Member could tolerate a high content of mud. Heliolitids dominate over the other taxa in diversity and abundance, while halysitids are represented by abundant specimens of only one species, Halysites senior. The collection includes one specimen of

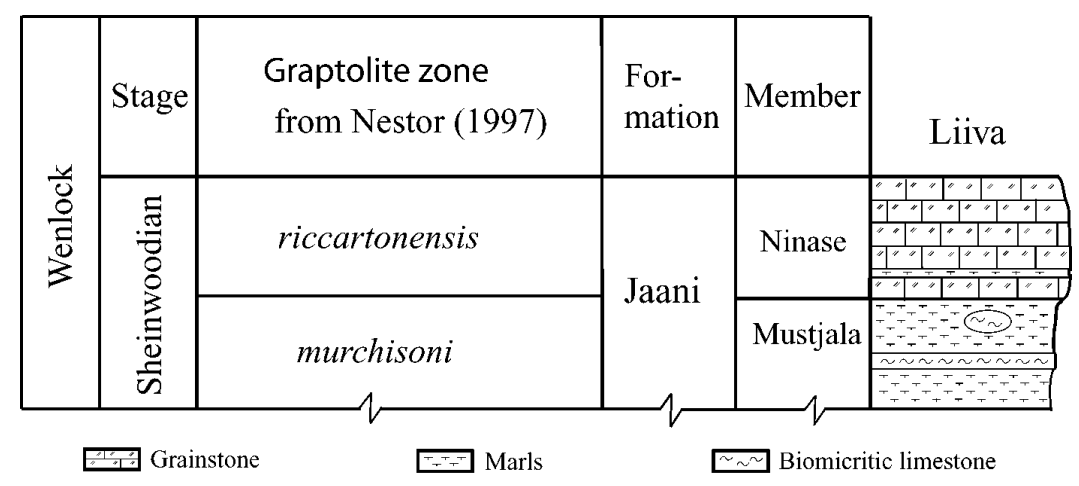

Fig. 2. Stratigraphical scheme with the lithological column of Liiva locality. 
Syringolites and Thecia. The Ninase Member contains fragments of brachiopods and crinoids, and also some tabulate corals (favositids) in the layers of marlstone intercalating with grainstone.

Klaamann $(1961,1964)$ has documented Thecia tenuicula Klaamann, Syringolites kunthianus (Lindström), Propora tubulata, Subalveolites sokolovi Klaamann, Paleofavosites secundus (Klaamann), and Catenipora oriens Klaamann from Liiva locality. The community, occurring in the Mustjala and Ninase members in localities of Northern Saaremaa, including Liiva, is called after the index fossil the Halysites senior community Klaamann (1983).

Rapid short-time influxes of mud interrupted the growth of coralla in the Mustjala Member. Coralla are mostly grown on stromatoporoids. The frequency of tabulates decreases at the transition from the Mustjala Member to the Ninase Member (from open shelf facies to shoal facies), but the taxonomic composition remains almost the same (Klaamann 1986). The shoal facies is usually rich in corals but, interestingly, here the situation is opposite. The environment in the Mustjala Member was most favourable for heliolitids, but the small number and size of favositids show that they could not adapt to the environment with that high sedimentation rate. Rare finds and the larger size of favositids in the Ninase Member confirm that they preferred the environment with a lower sedimentation rate and higher water dynamics.

Coralla are mainly of tabular and domical shape. The bulbous shape is less common and only one corallum is columnar (Table 1). The columnar shape of the corallum and upward growth usually indicate a high sedimentation rate (Young \& Scrutton 1991).

\section{ASPECTS OF VARIATION IN TABULATE CORALS}

The aspects of variation are observed at the corallum level, following Scrutton (1989).

Astogenetic variation is expressed at different stages of corallum development. The internal structure of a corallum at the juvenile stage may be completely different from the adult stage. This difference is visible in sections from small juvenile coralla of Propora tubulata (Pl. II, fig. 4) having heliolites-type coenenchymal tubes at an early stage (see also Noble \& Lee 1990). The crenulation of the corallite wall and the occurrence of septa in corallites of Heliolites interstinctus (Pl. I, fig. 5) is astogenetic (Lee et al. 1990).

Cyclomorphic variation or density banding occurs as a periodicity of dark and light bands (Scrutton 1989). The distinctness and character of density banding is variable among taxa (Young \& Kershaw 2005). Density banding in the current study is visible only in the spacing of tabulae in halysitids, favositids, and in Heliolites sp. A (Pl. II, figs 1, 6, 9). The density bands in H. spongodes? (Pl. I, fig. 4) and in H. interstinctus (P1. I, fig. 6) are expressed in the spacing of corallite tabulae and tubule tabulae. In H. spongodes? the density banding in the spacing of tubule tabulae is more distinct than that of corallite tabulae (see also Young \& Kershaw 2005). The density banding in Heliolites sp. A occurs only in the spacing 
Table 1. Size $(\mathrm{cm})$ and shape of coralla. W, corallum width; H, corallum height; M, height to the widest point of the corallum

\begin{tabular}{|c|c|c|c|c|}
\hline Species & $\mathrm{W}$ & $\mathrm{H}$ & $\mathrm{M}$ & Shape \\
\hline \multicolumn{5}{|c|}{ Heliolites spongodes? } \\
\hline TUG 1223-15 & 15 & 8 & 5 & Bulbous \\
\hline TUG 1223-22 & 6 & 3 & 3 & Bulbous \\
\hline TUG 1223-16 & 9.7 & 3.5 & 0 & Domical \\
\hline TUG 1223-23 & 9 & 3.5 & 0.5 & Domical \\
\hline TUG 1223-24 & 3.2 & 3.8 & 0.7 & Domical \\
\hline \multicolumn{5}{|c|}{ Heliolites interstinctus } \\
\hline TUG 1223-25 & 6 & 3 & 1.2 & Domical \\
\hline TUG 1223-18 & 7 & 2.5 & 1 & Domical \\
\hline TUG 1223-6 & 7 & 2.5 & 1 & Domical \\
\hline TUG 1223-26 & 2 & 1.3 & 0.5 & Domical \\
\hline TUG 1223-19 & 8 & 3 & 1 & Domical \\
\hline TUG 1223-27 & 5.5 & 2.5 & 2 & Bulbous \\
\hline TUG 1223-4 & 5.5 & 4 & 2 & Bulbous \\
\hline \multicolumn{5}{|l|}{ Heliolites sp. A } \\
\hline TUG 1223-7 & 4.2 & 6.7 & & Columnar \\
\hline \multicolumn{5}{|l|}{ Propora tubulata } \\
\hline TUG 1223-20 & 15 & 6 & & Tabular \\
\hline TUG 1223-21 & 15 & 5.7 & & Tabular \\
\hline TUG $1223-28$ & 8 & 3.5 & 1.8 & Bulbous \\
\hline TUG 1223-29 & 6 & 4.1 & 3.6 & Bulbous \\
\hline TUG 1223-8 & 8.5 & 3 & & Tabular \\
\hline TUG 1223-31 & 13.5 & 5 & & Tabular \\
\hline TUG 1223-32 & 6.3 & 2.5 & & Tabular \\
\hline TUG 1223-33 & 3.2 & 1.5 & 0.8 & Bulbous \\
\hline \multicolumn{5}{|l|}{ Halysites senior } \\
\hline TUG 1223-34 & 10 & 2 & & Tabular \\
\hline TUG 1223-35 & 6 & 6 & 3.5 & Bulbous \\
\hline TUG 1223-36 & 10.5 & 3 & & Tabular \\
\hline TUG 1223-37 & 9 & 3 & & Tabular \\
\hline \multicolumn{5}{|c|}{ Paleofavosites secundus? } \\
\hline TUG 1223-38 & 9 & 4 & 0 & Domical \\
\hline TUG 1223-13 & 7.5 & 2.2 & & Tabular \\
\hline TUG 1223-39 & 13 & 2.6 & & Tabular \\
\hline
\end{tabular}

\section{Explanation of Plate I}

Photographs of thin sections. All specimens from the Jaani Stage, Liiva locality. Figs 1-4. Heliolites spongodes? Lindström; 1-3, transverse sections, $\times 10$; 1, TUG 1223-1; 2, TUG 1223-23; 3, TUG 1223-2; 4, TUG 1223-3, vertical section, $\times 10$. Figs 5, 6. Heliolites interstinctus (Linnaeus); 5, TUG 1223-4, transverse section, $\times 8$; 6, TUG 1223-5, vertical section, $\times 9$. Fig. 7. Heliolites sp. A, TUG 1223-7, transverse section, $\times 11$. 
PLATE I
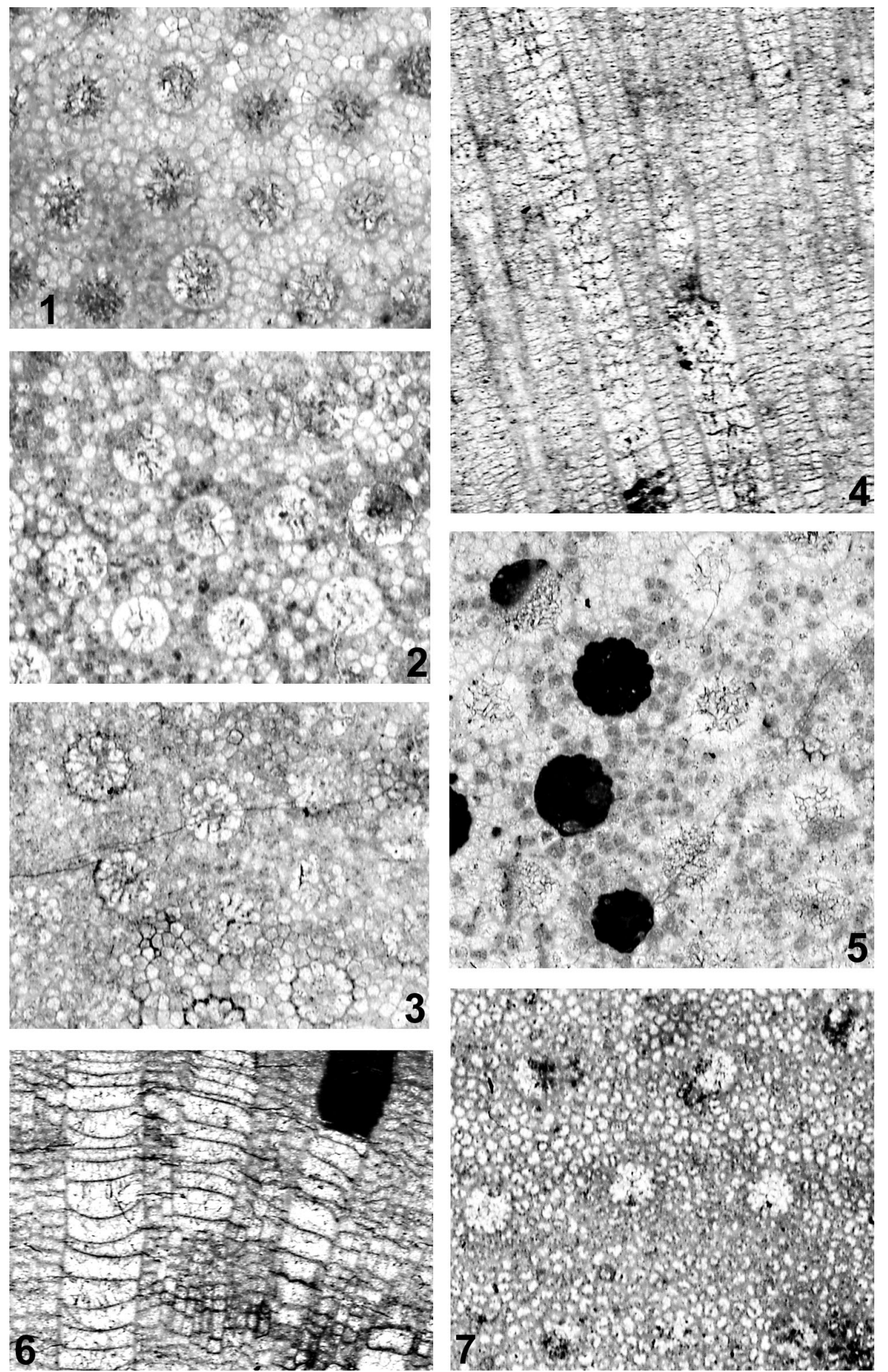
PLATE II
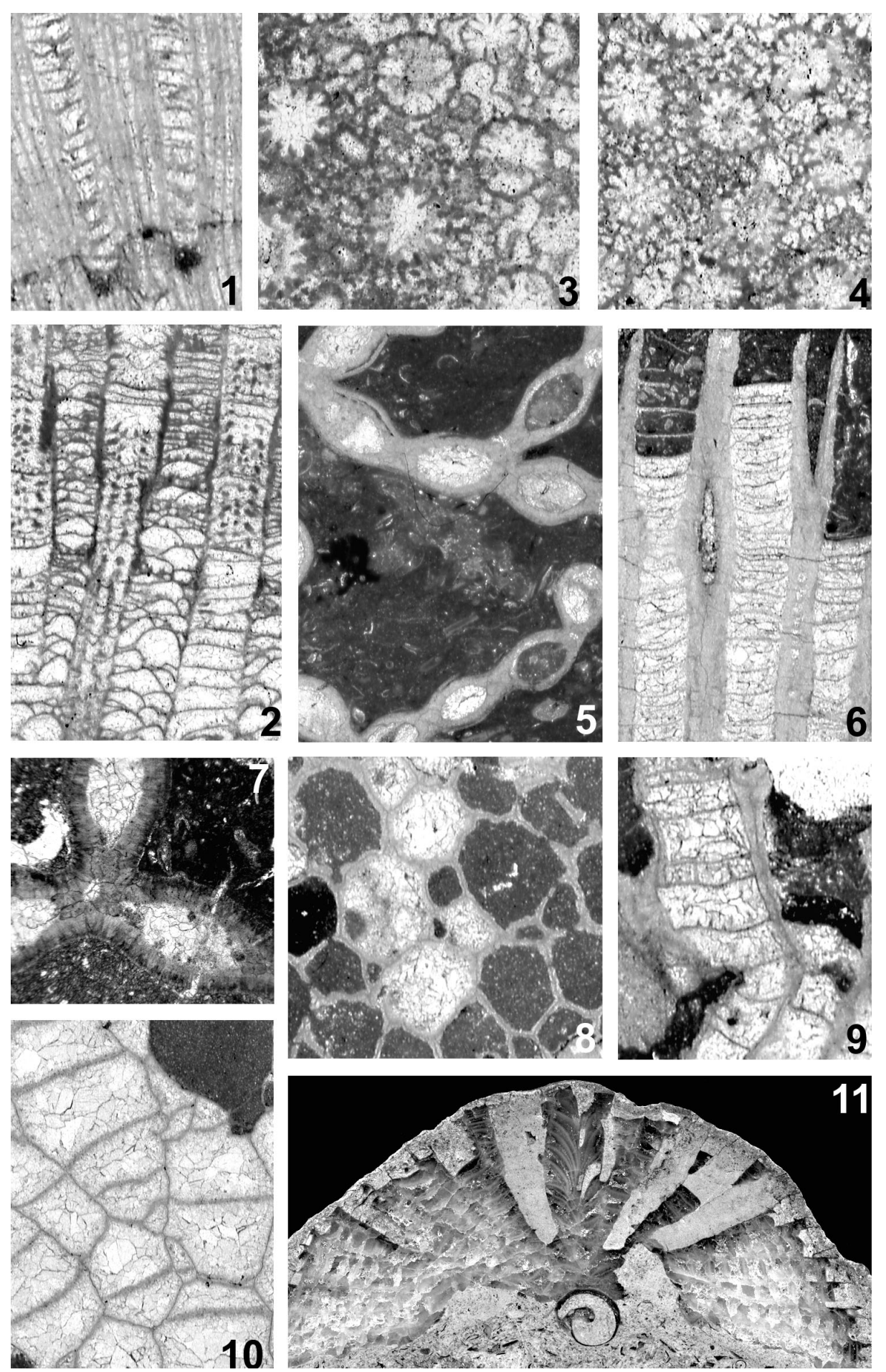
of corallite tabulae. Propora tubulata has distinctive bands, which are expressed in the spacing of tabulae and dissepiments and in periodical thickening of skeletal elements (Pl. II, figs 2, 3).

Topomorphic variation includes the variation in corallite size, shape, and spacing within the corallum (Scrutton 1989). These characters vary with the environmental conditions, but this variation is also genetically controlled as, for example, the corallum growth changes in response to the environment, depending on the plasticity of species (Young \& Scrutton 1991). Topomorphic variation can be also the degree of crenulation of corallites in H. spongodes? (Pl. I, figs 1-3) and thickening of corallite walls in Halysites senior (Pl. II, fig. 6). Variation in tabularium size and corallite spacing within the corallum is obvious in heliolitids (Fig. 3). In comparison with P. tubulata the variation in corallite wall thickness is low in species of Heliolites (Fig. 4).

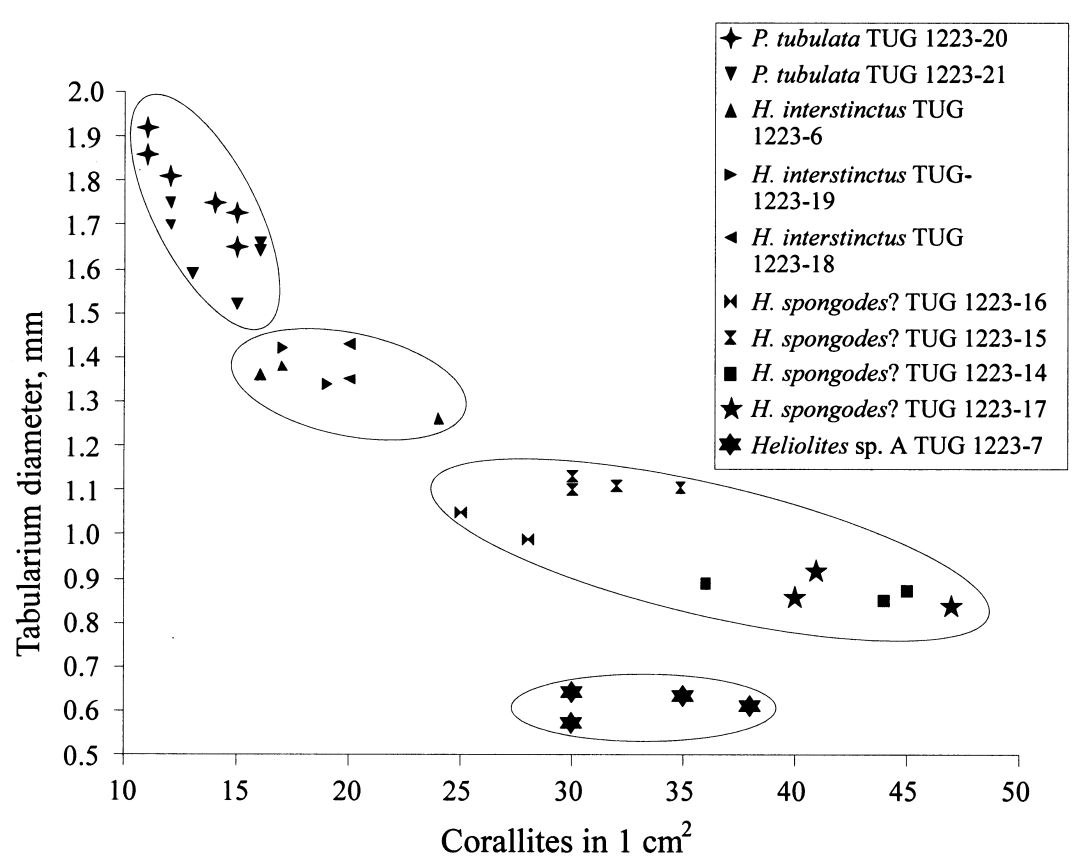

Fig. 3. Scatter plot of mean numbers of corallites in $1 \mathrm{~cm}^{2}$ versus mean values of tabularium diameter between different sections of selected heliolitid coralla.

\section{Explanation of Plate II}

Photographs of thin sections. All specimens from the Jaani Stage, Liiva locality. Fig. 1. Heliolites sp. A, TUG 1223-7, vertical section, $\times 10$. Figs 2-4. Propora tubulata (Lonsdale); 2, 3, TUG 1223-8, 2, vertical section, $\times 6$; 3, transverse section, $\times 10$; 4, TUG 1223-9, transverse section, $\times 8$. Figs 5, 6. Halysites senior Klaamann; 5, TUG 1223-10, transverse section, $\times 5$; 6, TUG 1223-11, vertical section, $\times 7$. Fig. 7. Catenipora oriens Klaamann; holotype, GIT 89-33, transverse section, $\times 16$. Figs $8-11$. Paleofavosites secundus? (Klaamann); 8, TUG 1223-12, transverse section, $\times 8$; 9, vertical section, $\times 11 ; 10$, TUG 1223-13, vertical section, $\times 5 ; 11$, section through the centre of the corallum, $\times 1.3$. 


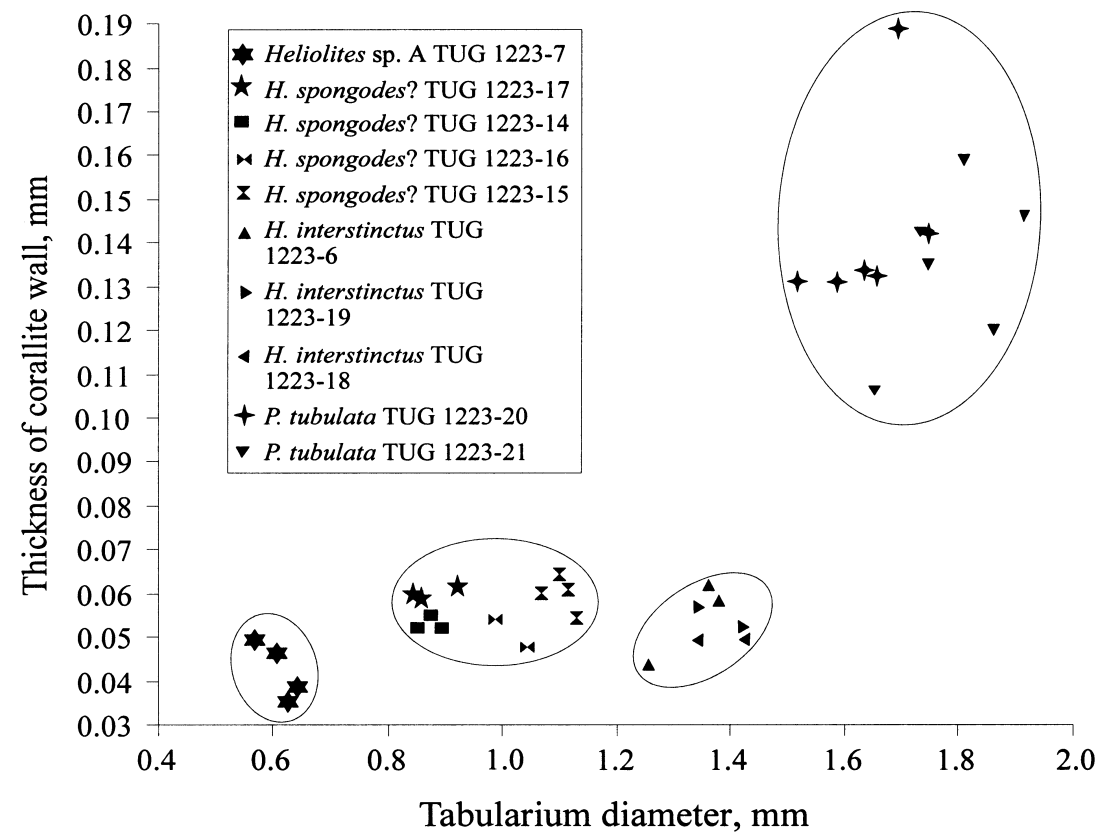

Fig. 4. Scatter plot of mean tabularium diameter versus mean thickness of corallite wall between different sections of selected heliolitid coralla.

\section{INTRASPECIFIC VARIATION AND TAXONOMY OF TABULATE CORALS}

Variations can be classified as occurring at individual, intraspecific, and interpopulational levels (Webb 1996). Intraspecific variation occurs at the next level after intracorallum variation.

The variation in quantitative characters of heliolitids, such as tabularium diameter, corallite spacing, and thickness of the corallite wall, is evident within coralla, but the degree of variation is higher between coralla (Figs 5, 6). This is also noticed by the comparison of the ranges of mean values of these characters (Tables 2, 3, 4).

Heliolites interstinctus differs from other heliolitids by the largest mean corallite size. Its wall is mostly smooth, but sometimes wavy, and corallites are slightly crenulated (Pl. I, fig. 5). The septa are absent in some corallites (Table 5). The variable occurrence of septa within the corallum in that species excludes the possibility of assigning specimens without septa to Heliolites decipiens M'Coy (Lee et al. 1990). Therefore, $H$. decipiens described by Klaamann (1961) from Saaremaa is a synonym of $H$. interstinctus and the latter species instead belongs to the Halysites senior community (Klaamann 1983).

Powell (1979) described Heliolites spongodes as a subspecies of $H$. daintreei Nicholson \& Etheridge from the Wenlock of England. The other subspecies 


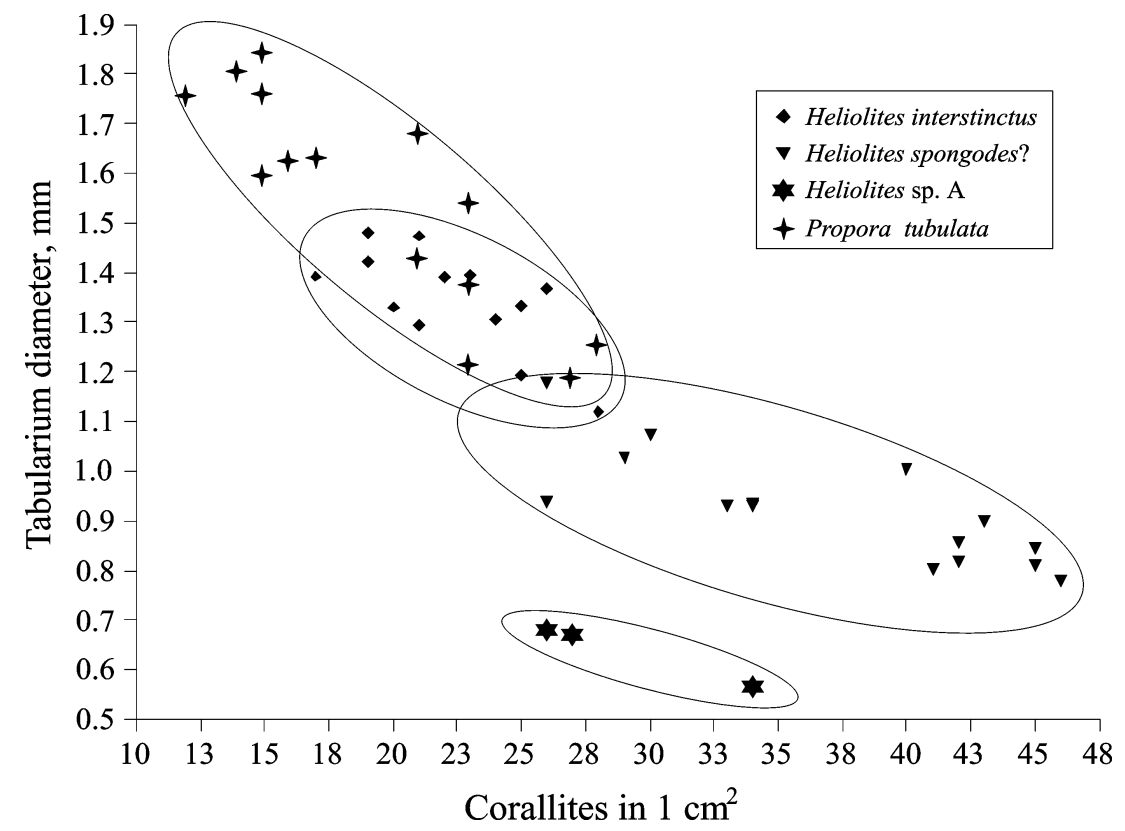

Fig. 5. Scatter plot of mean numbers of corallites in $1 \mathrm{~cm}^{2}$ versus mean values of tabularium diameter between different species of heliolitids.

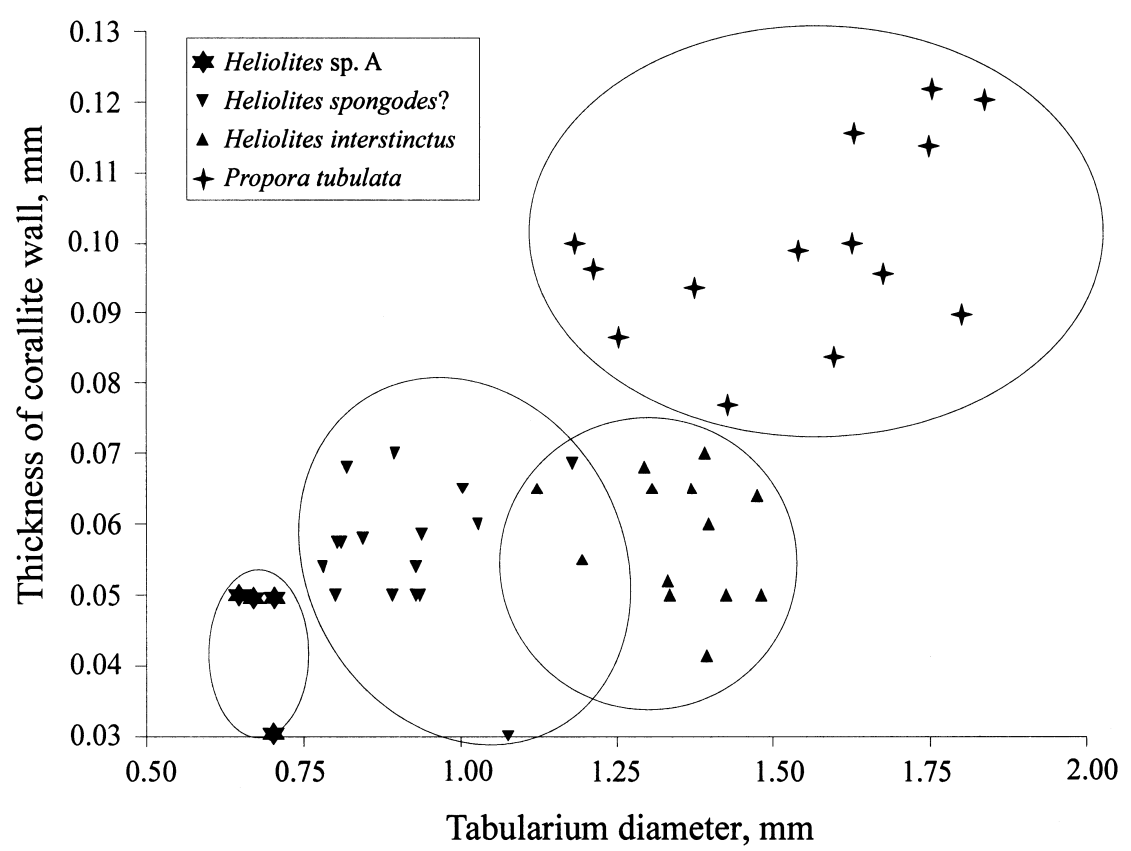

Fig. 6. Scatter plot of mean tabularium diameter versus mean thickness of corallite wall between different species of heliolitids. 
Table 2. The numerical data of coralla for Heliolites spongodes? Lindström, TUG 1223-14, TUG 1223-15, TUG 1223-16, TUG 1223-3; for Heliolites interstinctus (Linnaeus), TUG 1223-18, TUG 1223-6, TUG 1223-19; for Heliolites sp. A, TUG 1223-7; and for Propora tubulata (Lonsdale), TUG 1223-20, TUG 1223-21. TaD, tabularium diameter (mm); WT, thickness of corallite wall (mm); Co $1 \mathrm{~cm}^{2}$, number of corallites in $1 \mathrm{~cm}^{2}$; stdev., standard deviation; c.v., coefficient of variation

\begin{tabular}{|c|c|c|c|c|c|c|c|}
\hline & $\mathrm{TaD}$ & WT & $\begin{array}{c}\mathrm{Co} \\
1 \mathrm{~cm}^{2}\end{array}$ & & $\mathrm{TaD}$ & WT & $\begin{array}{c}\mathrm{Co} \\
1 \mathrm{~cm}^{2}\end{array}$ \\
\hline TUG 1223-14 & & & & TUG 1223-6 & & & \\
\hline Colony average & 0.87 & 0.05 & 41.67 & Colony average & 1.38 & 0.05 & 18 \\
\hline Range of means & $0.85-0.89$ & - & & Range of means & $1.34-1.42$ & - & \\
\hline Stdev. of colony & 0.04 & 0.01 & & Stdev. of colony & 0.06 & 0.01 & \\
\hline C.v. of colony & 4.64 & 13.21 & & C.v. of colony & 4.23 & 13.32 & \\
\hline TUG 1223-15 & & & & TUG 1223-19 & & & \\
\hline Colony average & 1.1 & 0.06 & 32 & Colony average & 1.33 & 0.05 & 11.08 \\
\hline Range of means & $1.07-1.13$ & - & & Range of means & $1.26-1.38$ & - & \\
\hline Stdev. of colony & 0.05 & 0.01 & & Stdev. of colony & 0.07 & 0.01 & \\
\hline C.v. of colony & 4.71 & 13.58 & & C.v. of colony & 5.51 & 24.68 & \\
\hline TUG 1223-16 & & & & TUG 1223-7 & & & \\
\hline Colony average & 1.02 & 0.05 & 26.5 & Colony average & 0.61 & 0.14 & 33.25 \\
\hline Range of means & $0.99-1.05$ & - & & Range of means & $0.57-0.64$ & - & \\
\hline Stdev. of colony & 0.08 & 0.01 & & Stdev. of colony & 0.05 & 0.03 & \\
\hline C.v. of colony & 8.14 & 17.29 & & C.v. of colony & 7.51 & 22.24 & \\
\hline TUG 1223-3 & & & & TUG $1223-20$ & & & \\
\hline Colony average & 0.87 & 0.06 & 42.67 & Colony average & 1.79 & 0.13 & 13 \\
\hline Range of means & $0.84-0.92$ & - & & Range of means & $1.65-1.92$ & $0.11-0.16$ & \\
\hline Stdev. of colony & 0.04 & 0.01 & & Stdev. of colony & 0.13 & 0.03 & \\
\hline C.v. of colony & 4.88 & 15.91 & & C.v. of colony & 7.47 & 20.52 & \\
\hline TUG 1223-18 & & & & TUG 1223-21 & & & \\
\hline Colony average & 1.39 & 0.05 & 20 & Colony average & 1.64 & 0.14 & 14 \\
\hline Range of means & $1.35-1.43$ & - & & Range of means & $1.52-1.75$ & $0.13-0.19$ & \\
\hline Stdev. of colony & 0.08 & 0.01 & & Stdev. of colony & 0.11 & 0.03 & \\
\hline C.v. of colony & 5.60 & 13.35 & & C.v. of colony & 6.50 & 22.24 & \\
\hline
\end{tabular}

H. daintreei daintreei in Powell (1979) has slightly larger corallite diameters $(1.08-1.35 \mathrm{~mm})$ and a more variable corallite shape than the first subspecies, which has smaller $(0.65-0.83 \mathrm{~mm}$ across $)$ and slightly crenulated corallites. Powell (1979) noted that the corallite of the type specimen of $H$. daintreei from the Devonian of North Queensland varies largely in diameter $(0.5-2.5 \mathrm{~mm})$. Both subspecies have long septal spines. The specimens analysed in the current work have mean tabularium diameters of $0.78-1.18 \mathrm{~mm}$, which overlap with corallite 


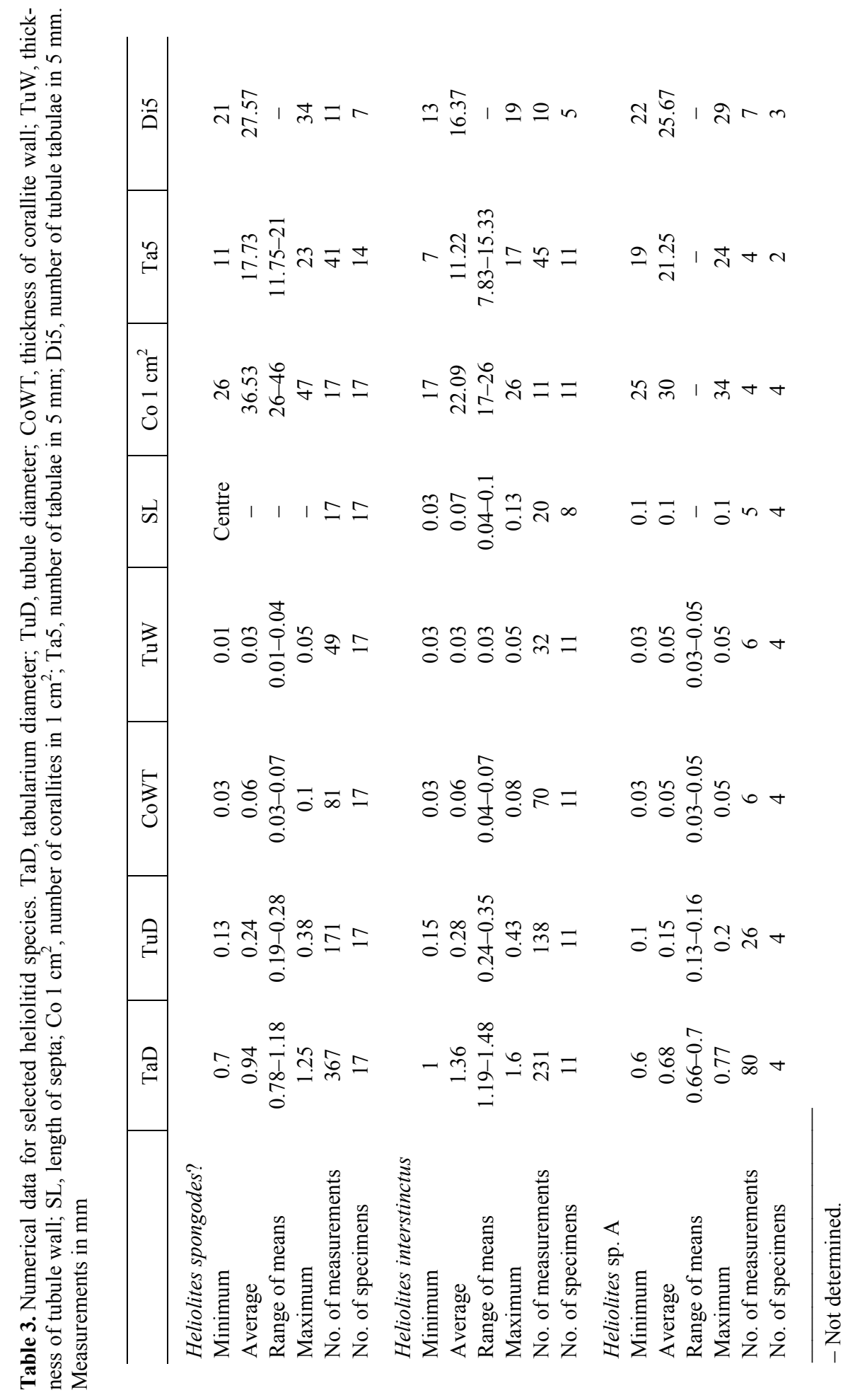


Table 4. Numerical data for Propora tubulata (Lonsdale). TaD, tabularium diameter (mm); WT, thickness of corallite wall $(\mathrm{mm})$; SL, length of septa $(\mathrm{mm})$; Co $1 \mathrm{~cm}^{2}$, number of corallites in $1 \mathrm{~cm}^{2}$; Ta5, number of tabulae in $5 \mathrm{~mm}$; Se5, number of septa in $5 \mathrm{~mm}$; Di5, number of tubule tabulae in $5 \mathrm{~mm}$

\begin{tabular}{l|c|c|c|c|c|c|c}
\hline & TaD & WT & SL & $\begin{array}{c}\text { Co } \\
1 \mathrm{~cm}^{2}\end{array}$ & Ta5 & Se5 & Di5 \\
\hline Minimum & 0.85 & 0.05 & 0.35 & 12 & 7 & 7 & 4 \\
Average & 1.55 & 0.11 & 0.52 & 19.29 & 12.1 & 14.64 & 10.44 \\
Range of means & $1.19-1.95$ & $0.08-0.22$ & $0.4-0.7$ & $12.0-28.0$ & $8.4-17.0$ & $10.0-21.67$ & $6.0-16.67$ \\
Maximum & 2 & 0.9 & 0.7 & 28 & 18 & 23 & 20 \\
$\begin{array}{l}\text { No. of measure- } \\
\quad \text { ments }\end{array}$ & 292 & 104 & 17 & 14 & 50 & 47 & 45 \\
$\quad$ No. of specimens & 14 & 14 & 12 & 14 & 12 & 12 & 12
\end{tabular}

Table 5. Occurrence of septa in different sections of selected specimens of Heliolites interstinctus (Linnaeus). Co with Spt, corallites with septa; Co total, corallites in total; percent, percentage of corallites with septa in the section of the corallum

\begin{tabular}{lcccc}
\hline & Co with Spt & Co total & Percent \\
\hline TUG 1223-18 & \multicolumn{3}{l}{} \\
Peel 1 & 0 & 46 & 0 \\
Peel 2 & 2 & 85 & 2.35 \\
TUG 1223-19 & & & \\
Peel 1 & 3 & 35 & 8.57 \\
Peel 2 & 11 & 75 & 14.67 \\
TUG 1223-6 & & & \\
Peel 1 & 0 & 35 & 0 \\
Peel 2 & 3 & 90 & 3.33 \\
Peel 3 & 2 & 85 & 2.35
\end{tabular}

diameters of both subspecies of $H$. daintreei, but are smaller than those of the type specimen of $H$. daintreei from North Queensland. Here the specimens are considered to be more similar to $H$. spongodes. However, proper description of this species requires more material and therefore it is regarded as tentative. Heliolites spongodes? is quite similar to Heliolites diligens Bondarenko from the LudlovianGedinnian of Kazakhstan according to the descriptions of Dixon (1989) who analysed the latter species from the Ludlow of the Canadian Arctic. They both have long septal spines and variable shape of corallites, and also similar quantitative characters $(H$. diligens has corallite diameters of $1-1.3 \mathrm{~mm}$, tubule diameters of 0.26-0.4 mm, and corallites 24-46 per $\mathrm{cm}^{2}$ ). For numerical data of $H$. spongodes? see Table 3. Heliolites diligens has also short or undeveloped septa (Dixon 1989), but $H$. spongodes? has long septal spines in all corallites from all sections of coralla. 
The intraspecific variation in H. spongodes?, except for quantitative characters, occurs in corallite shape, which is circular (Pl. I, fig. 1), slightly crenulate (Pl. I, fig. 2) or strongly crenulate (Pl. I, fig. 3). The shape of the corallite wall varies from smooth to wavy, whereas variation is more distinct between specimens than within the corallum (Pl. I, fig. 2). The crenulation of the corallite wall in this species is environmentally affected, because it appears randomly in some coralla and strongly and more often in other coralla (Pl. I, figs 2, 3; Dixon 1989). Slight difference is noted in the abundance of septal spines, but they all reach the corallite centre and are well developed (Pl. I, figs 1-4). Some specimens have corallites with long horizontal septal spines, which almost meet at the centre of the corallite or form different axial structures (Pl. I, fig. 3). Those specimens look like different representatives of Stelliporellidae (Hill 1981). Stelliporellids differ from heliolitids basically in having long septa, which form different structures inside corallites.

Heliolites sp. A is represented only by 4 specimens. It differs from other heliolitids mostly in its small corallite size (P1. I, fig. 7; P1. II, fig. 1; Figs 3-6). Corallite sizes and the thickness of the corallite wall vary within and between specimens of Heliolites sp. A (Tables 2, 3; Figs 3-6). This species has short septa and thick skeletal elements (Pl. I, fig. 7; Pl. II, fig. 1). Unlike other tabulates, it also has a corallum of columnar shape (Table 1).

Propora tubulata has the most distinct density bands among heliolitids and, therefore, skeletal elements, such as corallite wall, coenenchymal dissepiments, and septal spines, vary from thin to thick (Table 4). This species has the largest intraspecific variation in corallite size compared to Heliolites species (Fig. 5). However, the coefficient of variation of selected coralla does not clearly show that there is a distinct difference in intracorallum variation of $P$. tubulata and other heliolitids (Table 2). Propora raricellata Sokolov is a possible synonym of P. tubulata because they differ only in the spacing of corallites (Sokolov 1955) which is a variable character (Figs 3, 5). Propora conferta Milne-Edwards \& Haime from the Jaani Formation of Saaremaa is identical to P. tubulata and therefore it cannot belong to the Halysites senior community (Klaamann 1961, 1983).

Halysites senior is the only halysitid species in Liiva locality. It has polygonal lacunae somewhat varying in size and shape, thick corallite walls and septal spines (Pl. II, figs 5, 6). Corallite sizes are slightly variable inside the corallum (P1. II, fig. 5; Table 6). Wall thickness and development of septal spines are variable as well (Table 7). The corallite wall in H. senior is sometimes so thick that tubules cannot be noticed, as already noted by Mõtus \& Klaamann (1999). The presence or absence of tubules, however, is the character of generic importance. The same character varies within the corallum and between specimens (Tables 6, 7). Describing Catenipora oriens, Klaamann (1961) did not notice tubules in this species, but they are present in the holotype (Pl. II, fig. 7). By the overlapping metric characters $C$. oriens and $H$. senior are possibly synonymous with each other. The corallites in the latter are 1.4-1.9 mm wide, 1.8-2.2 $\mathrm{mm}$ long, and have thick walls (Mõtus \& Klaamann 1999), whereas corallites in C. oriens are slightly smaller, 1.0-1.4 mm wide and 1.5-1.9 $\mathrm{mm}$ long, but have also thick walls and long septal spines. 
The development of septal spines is variable in H. senior and corallite sizes are overlapping with each other.

Paleofavosites secundus? is the only favositid in the locality. It is represented only by 7 specimens, which are up to $13 \mathrm{~cm}$ wide and $4 \mathrm{~cm}$ high in the Ninase

Table 6. Size and number of tabulae compared with the size and number of tubules in selected coralla of Halysites senior Klaamann. TaL, tabularium length; TuL, tubule length; TuW, tubule width; No. of Co, number of corallites; No. of Tu, number of tubules; stdev., standard deviation; c.v., coefficient of variation. Measurements in $\mathrm{mm}$

\begin{tabular}{|c|c|c|c|c|c|}
\hline & $\mathrm{TaL}$ & TuL & TuW & No. of Co & No. of Tu \\
\hline \multicolumn{6}{|l|}{ TUG $1223-40$} \\
\hline Minimum & 1.4 & 0.15 & 0.15 & 33 & 4 \\
\hline Average & 1.63 & 0.26 & 0.34 & 45.67 & 7 \\
\hline Range of means & $1.61-1.66$ & - & - & - & - \\
\hline Maximum & 2 & 0.6 & 0.75 & 60 & 12 \\
\hline Stdev. & 0.14 & - & - & - & - \\
\hline C.v. & 8.7 & - & - & - & - \\
\hline No. of measurements & 55 & 21 & 21 & 3 & 3 \\
\hline \multicolumn{6}{|l|}{ TUG 1223-36 } \\
\hline Minimum & 1 & 0.1 & 0.1 & 84 & 15 \\
\hline Average & 1.49 & 0.25 & 0.28 & 88 & 17 \\
\hline Range of means & $1.47-1.51$ & - & - & - & - \\
\hline Maximum & 1.9 & 0.75 & 0.7 & 92 & 19 \\
\hline Stdev. & 0.18 & - & - & - & - \\
\hline C.v. & 11.94 & - & - & - & - \\
\hline No. of measurements & 88 & 35 & 35 & 2 & 2 \\
\hline
\end{tabular}

Table 7. Numerical data for Halysites senior Klaamann. TaL, tabularium length; TaW, tabularium width; TuL, tubule length; TuW, tubule width; No. of Co, number of corallites in section; No. of Tu, number of tubules in section; WT, corallite wall thickness; SL, length of septa; Ta5, number of tabulae in $5 \mathrm{~mm}$. Measurements in $\mathrm{mm}$

\begin{tabular}{l|c|c|c|c|c|c|c|c|c}
\hline & TaL & TaW & TuL & TuW & $\begin{array}{c}\text { No. } \\
\text { of Co }\end{array}$ & $\begin{array}{c}\text { No. } \\
\text { of Tu }\end{array}$ & WT & SL & Ta5 \\
\hline Minimum & 0.8 & 0.5 & 0.05 & 0.05 & 34 & 1 & 0.3 & 0.05 & 8 \\
Average & 1.49 & 0.94 & 0.24 & 0.26 & 52.8 & 5.7 & 0.4 & 0.14 & 11.46 \\
Range of means & $1.33-1.78$ & $0.84-1.24$ & $0.13-0.3$ & $0.17-0.46$ & - & - & $0.3-0.5$ & $0.1-0.3$ & $9.83-14$ \\
Maximum & 2 & 1.2 & 0.75 & 0.6 & 95 & 14 & 0.6 & 0.3 & 16 \\
$\begin{array}{l}\text { No. of measure- } \\
\quad \text { ments }\end{array}$ & 223 & 223 & 58 & 58 & 10 & 10 & 76 & 20 & 42 \\
\begin{tabular}{l} 
No. of specimens \\
\hline
\end{tabular} & 10 & 10 & 10 & 10 & 10 & 10 & 10 & 9 & 10 \\
\hline
\end{tabular}

- Not determined. 
Member but only a few centimetres wide in the Mustjala Member. The specimens from the Mustjala Member resemble Paleofavosites secundus in similar mean sizes of corallites, wall thickness, position of pores, and in having septa on tabulae (Table 8; Pl. II, fig. 9). In Paleofavosites secundus corallites are $1.5-2.1 \mathrm{~mm}$ in size and the corallite wall is $0.12-0.2 \mathrm{~mm}$ thick (Klaamann 1964). The species was earlier known under Mesofavosites, but Mesofavosites is synonymous with Paleofavosites (Powell \& Scrutton 1978). Most specimens from the Ninase Member, except for one, are similar to Favosites jaaniensis Sokolov, which has an average corallite diameter of $1.7-4.0 \mathrm{~mm}$ and corallite wall thickness of 0.05-0.07 $\mathrm{mm}$, sometimes $0.1 \mathrm{~mm}$. The diagnostic characters partly overlap in all specimens (Tables 8,9). Most specimens from the Ninase Member have some larger corallites and a slightly thinner corallite wall than the specimens from the Mustjala Member. One specimen from the Ninase Member has mean corallite size and wall thickness falling between the same characters of $P$. secundus and F. jaaniensis (TUG 1223-39, Table 8). The position of pores varies in all specimens. The presence of few corner pores in F. jaaniensis shows that this species should be assigned to Paleofavosites. Yet, $P$. jaaniensis erected by Sokolov is very different from $F$. jaaniensis (Sokolov 1952). Paleofavosites jaaniensis Sokolov has large pores and well-developed septal spines. Klaamann (1986)

Table 8. Variation in selected characters of Paleofavosites secundus? (Klaamann). CoD-6, mean diameters of corallites with 6 or more sides $(\mathrm{mm})$; WT, mean thickness of corallite wall $(\mathrm{mm})$; $\mathrm{CP}$, presence or absence of corner pores

\begin{tabular}{l|c|l|l|l}
\hline & CoD-6 & WT & CP & Member \\
\hline TUG 1223-38 & 3.2 & 0.1 & Present & Ninase \\
TUG 1223-41 & 3.0 & 0.1 & Absent & Ninase \\
TUG 1223-42 & 1.7 & 0.2 & Absent & Mustjala \\
TUG 1223-39 & 2.3 & 0.3 & Absent & Ninase \\
TUG 1223-13 & 3.4 & 0.1 & Present & Ninase \\
TUG 1223-43 & 1.9 & 0.4 & Present & Mustjala \\
TUG 1223-12 & 1.7 & 0.2 & Absent & Mustjala
\end{tabular}

Table 9. Numerical data for Paleofavosites secundus? (Klaamann). CoD-6, diameters of corallites with 6 or more sides; WP, diameter of wall pores; CP, diameter of corner pores; WT, thickness of corallite wall; SL, length of septa; Ta5, number of tabulae in $5 \mathrm{~mm}$. Measurements in $\mathrm{mm}$

\begin{tabular}{lcccccccc}
\hline & CoD-6 & WP & CP & WT & SL & Ta5 \\
\hline Minimum & 0.68 & 0.05 & 0.1 & 0.05 & 0.1 & 2 \\
Average & 2.54 & 0.19 & 0.18 & 0.24 & 0.11 & 3.92 \\
Range of means & $1.68-3.38$ & $0.1-0.29$ & $0.1-0.25$ & $0.05-0.43$ & $0.1-5.14$ & $2.0-5.0$ \\
Maximum & 4.75 & 0.45 & 0.25 & 0.5 & 0.15 & 6 \\
No. of measurements & 133 & 26 & 4 & 14 & 7 & 18 \\
No. of specimens & 7 & 7 & 3 & 7 & 4 & 4
\end{tabular}


mentioned that $F$. jaaniensis is synonymous with Favosites gothlandicus Lamarck. The latter species has smaller corallites, thin walls, and mid-wall pores according to the neotype (Jones 1936, p. 9). It is assumed here that Favosites jaaniensis is probably synonymous with Paleofavosites secundus. More specimens are needed to solve this taxonomic problem and the specimens here are referred to as Paleofavosites secundus?. The difficulty is rare occurrence of favositids in Liiva locality, but additional material should be collected from the same stratigraphical level in other localities.

Favositids are known to have the largest intracorallum variation in corallite size among tabulate corals (Young \& Elias 1997). Their simple compact structure complicates the determination of intraspecific variation. The specimens from the Mustjala Member have a thick corallite wall and they have settled on stromatoporoids (Pl. II, figs 8, 9). In the Ninase Member they have settled on small fossils such as gastropods and grown more in size because of the better conditions (Pl. II, figs 10,11). The difference between the two environments could lead to large intraspecific variation in Paleofavosites secundus?.

\section{CONCLUSIONS}

1. The environment with a high sedimentation rate and low energy dynamics in the Mustjala Member was most favourable for heliolitids.

2. The range of diagnostic characters of Halysites senior overlaps with that of Catenipora oriens and the two species are regarded as synonyms.

3. Propora raricellata is possibly synonymous with $P$. tubulata because the only character differentiating these species is variable.

4. The very small number of favositids shows that they had difficulties in adapting themselves to the environmental conditions in Liiva locality.

5. Favosites jaaniensis is possibly synonymous with Paleofavosites secundus because their characters varied with the environment.

\section{ACKNOWLEDGEMENTS}

The research was supported by grants Nos 6127 and 5290 of the Estonian Science Foundation. Prof. Dimitri Kaljo (Institute of Geology at Tallinn University of Technology) and Dr. Oive Tinn (Institute of Geology, University of Tartu) are thanked for the constructive reviews of the manuscript. Dr. Heldur Nestor (Institute of Geology at Tallinn University of Technology) is acknowledged for advice in lithology of the locality, Prof. Tõnu Meidla (University of Tartu) for help during fieldwork for this study in 1998, Dr. Graham Young (Manitoba Museum) for discussing details of terminology and statistics, and Dr. John Powell (British Geological Survey) for the valuable information about species. 


\section{REFERENCES}

Dixon, O. 1989. Species definition in heliolitine corals of the lower Douro Formation (Upper Silurian), Canadian Arctic. J. Paleont., 63, 819-838.

Dixon, O. 1999. Upper Silurian heliolitine corals, Canadian Arctic: taxonomic method, keys to identification, and biogeographic relationships. J. Paleont., 73, 1002-1014.

Hill, D. 1981. Rugosa and Tabulata. In Treatise on Invertebrate Paleontology, Part F, Coelenterata (Teichert, C., ed.). The Geological Society of America, Inc. and the University of Kansas.

Jones, O. A. 1936. The controlling effect of the environment upon the corallum in Favosites; with a revision of some massive species on this basis. Ann. Mag. Nat. Hist., 17, 1-24.

Klaamann, E. 1959. On the Tabulata fauna in Juuru and Tamsalu Stages. Eesti NSV Tead. Akad. Toim., 8, 256-270 (in Russian).

Klaamann, E. 1961. Tabulates and heliolitids from Wenlock of Estonia. Eesti NSV Tead. Akad. Geol. Inst. Uurim., 6, 69-112 (in Russian).

Klaamann, E. 1962a. Upper Silurian Tabulata of Estonia. Eesti NSV Tead. Akad. Geol. Inst. Uurim., 9, 25-74 (in Russian).

Klaamann, E. 1962b. Distribution of Tabulata in the Ordovician and Silurian of Estonia (with a description of some new species). Eesti NSV Tead. Akad. Geol. Inst. Uurim., 10, 149-172 (in Russian).

Klaamann, E. 1964. Late Ordovician and Early Silurian Favositida from Estonia. Eesti NSV Teaduste Akadeemia Geoloogia Instituut (in Russian).

Klaamann, E. 1966. The Incommunicate Tabulata of Estonia. Eesti NSV Teaduste Akadeemia Geoloogia Instituut (in Russian).

Klaamann, E. 1970. Veränderlichkeit und taxonomische Stellung der Angopora hisingeri (Jones). Eesti NSV Tead. Akad. Toim. Keemia Geol., 19, 62-68 (in Russian).

Klaamann, E. 1983. Tabulates from Jaani and Jaagarahu stages (Wenlock of Estonia) and their biozones. In Paleontologiya drevnego paleozoya Pribaltiki i Podolii (Klaamann, E., ed.), pp. 3-40. Institute of Geology, Academy of Sciences of Estonia (in Russian).

Klaamann, E. 1986. The tabulate communities and biozones of the East Baltic Silurian. In Theory and Practice of Ecostratigraphy (Kaljo, D. \& Klaamann, E., eds), pp. 80-98. Institute of Geology, Academy of Sciences of the Estonian SSR (in Russian).

Lee, D.-J., Young, G. A. \& Noble, P. A. 1990. Heterochronic evolution in the Heliolites interstinctusdecipiens lineage of the Chaleur Bay region, eastern Canada. Lethaia, 23, 11-20.

Mõtus, M.-A. \& Klaamann, E. 1999. The halysitid coral genera Halysites and Cystihalysites from Gotland, Sweden. GFF, 121, 81-90.

Nestor, H. 1997. Sedimentary cover, Silurian. In Geology and Mineral Resources of Estonia (Raukas, A. \& Teedumäe, A., eds), pp. 89-106. Estonian Academy Publishers, Tallinn.

Noble, J. P. A. \& Lee, D.-J. 1990. Ontogenies and astogenies, their significance in some favositid and heliolitid corals. J. Paleont., 64, 515-523.

Powell, J. 1979. Palaeoecology and taxonomy of some Wenlock tabulate corals and stromatoporoids. Unpubl. Ph. D. thesis, University of Leeds.

Powell, J. H. \& Scrutton, C. T. 1978. Variation in the Silurian tabulate coral Paleofavosites asper, and the status of Mesofavosites. Palaeontology, 21, 307-319.

Scrutton, C. T. 1989. Intracolonial and intraspecific variation in tabulate corals. Mem. Ass. Australas. Palaeontols, 8, 33-43.

Scrutton, C. T. 1998. The Palaeozoic corals, II: structure, variaton and palaeoecology. Yorkshire Geol. Soc. Proc., 52, 1-57.

Simpson, G. G., Roe, A. \& Lewontin, F. C. 1960. Quantitative Zoology. Revised edition. Hartcourt, Brace, and Company, New York.

Sokolov, B. S. 1951a. Tabulates from the Paleozoic of the European part of the SSSR (Ordovician of the West Urals and East Baltic area). Tr. VNIGRI, 48, 1-132 (in Russian). 
Sokolov, B. S. 1951b. Tabulates from the Paleozoic of the European part of the SSSR. Silurian of the East Baltic area, II (favositids from the Llandovery Series). Tr. VNIGRI, 52, 1-124 (in Russian).

Sokolov, B. S. 1952. Tabulates from the Paleozoic of the European part of the SSSR. Silurian of the East Baltic area, Part III (favositids from the Wenlock and Ludlow series). Tr. VNIGRI, 58, $1-85$ (in Russian).

Sokolov, B. S. 1955. Tabulates from the Paleozoic of the European part of the SSSR. Introduction (General aspects of systematics and evolution of tabulates). Tr. VNIGRI, 85 (in Russian).

Stasinska, A. 1967. Tabulata from Norway, Sweden and from the erratic boulders of Poland. Palaeont. Polonica, 18.

Stel, J. H. 1978. Environment and quantitative morphology of some Silurian tabulates from Gotland. Scripta Geol., 47, 1-75.

Webb, G. E. 1996. Morphological variation and homoplasy: the challenge of Paleozoic coral systematics. Paleont. Soc. Pap., 1, 135-157.

Young, G. A. \& Elias, R. J. 1995. Latest Ordovician to earliest Silurian colonial corals of the eastcentral United States. Bulls. Am. Paleont., 108, 1-148.

Young, G. A. \& Elias, R. J. 1997. Patterns of variation in Late Ordovician and Early Silurian tabulate corals. Bol. R. Soc. Esp. Hist. Nat. (Sec. Geol.), 91, 193-204.

Young, G. A. \& Kershaw, S. 2005. Classification and controls of the internal banding in Palaeozoic stromatoporoids and colonial corals. Palaeontology, 48, 623-651.

Young, G. A. \& Scrutton, C. T. 1991. Growth form in Silurian heliolitid corals: the influence of genetics and environment. Paleobiology, 17, 369-387.

\title{
Saaremaa Wenlocki tabulaatide liigisisene muutlikkus ja selle seosed taksonoomiaga
}

\author{
Mari-Ann Mõtus
}

Põhja-Saaremaa rannikul asuv Liiva panga paljand on eriline tabulaatide arvukuse poolest. Enamik eksemplare pärineb Jaani lademe Mustjala kihistikust ja vaid mõni üksik eksemplar liigist Paleofavosites secundus? on pärit Ninase kihistikust. Heliolitiidid ja halüsitiidid domineerivad Mustjala kihistikus, kuna nad talusid sette kuhjumist paremini kui favositiidid, mis esinevad üksikute eksemplaridena mõlemas kihistikus. Tabulaatide muutlikkuses eristatakse koloonia- ja liigisisest muutlikkust. Liigid erinevad üksteisest liigisisese muutlikkuse iseloomu ja ulatuse poolest. Diagnostilised tunnused liigisisese muutlikkuse analüüsimisel on osutunud mõnedel liikidel omavahel kattuvateks. Halysites senior ja Catenipora oriens on ilmselt sünonüümid tunnuste kattumise poolest. Liigi muutlikkuse uurimisel on selgunud, et liikide Favosites jaaniensis ja Paleofavosites secundus diagnostilised tunnused muutuvad, mille tõttu kaks liiki võivad olla sünonüümid. Propora tubulata ja $P$. raricellata on sarnased ja neid eristav tunnus on muutlik. Üks liik on käsitletud avatud nomenklatuuris ja kaks liiki on küsimärgiga, sest ühe paljandi üksikutest eksemplaridest ei piisa nende täpseks kirjeldamiseks. 